Prepared for the U.S. Department of Energy

under Contract DE-AC05-76RL01830

\title{
Reactive Air Aluminization
}

\author{
J.P. Choi \\ Y.S. Chou \\ J.W. Stevenson
}

Pacific Northwest National Laboratory, Richland, WA

October 2011 


\title{
DISCLAIMER
}

This report was prepared as an account of work sponsored by an agency of the United States Government. Neither the United States Government nor any agency thereof, nor Battelle Memorial Institute, nor any of their employees, makes any warranty, express or implied, or assumes any legal liability or responsibility for the accuracy, completeness, or usefulness of any information, apparatus, product, or process disclosed, or represents that its use would not infringe privately owned rights. Reference herein to any specific commercial product, process, or service by trade name, trademark, manufacturer, or otherwise does not necessarily constitute or imply its endorsement, recommendation, or favoring by the United States Government or any agency thereof, or Battelle Memorial Institute. The views and opinions of authors expressed herein do not necessarily state or reflect those of the United States Government or any agency thereof.

\author{
PACIFIC NORTHWEST NATIONAL LABORATORY \\ operated by \\ BATTELLE \\ for the \\ UNITED STATES DEPARTMENT OF ENERGY \\ under Contract DE-AC05-76RL01830
}

Printed in the United States of America

Available to DOE and DOE contractors from the

Office of Scientific and Technical Information,

P.O. Box 62, Oak Ridge, TN 37831-0062;

ph: (865) 576-8401

fax: $(865) 576-5728$

email: reports@adonis.osti.gov

\footnotetext{
Available to the public from the National Technical Information Service, U.S. Department of Commerce, 5285 Port Royal Rd., Springfield, VA 22161 ph: (800) 553-6847 fax: $(703) 605-6900$

email: orders@ntis.fedworld.gov

online ordering: http://www.ntis.gov/ordering.htm
}

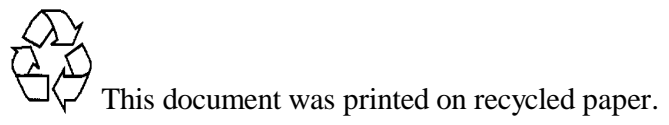


PNNL-20859

\section{Reactive Air Aluminization}

JP Choi

YS Chou

JW Stevenson

October 2011

Prepared for the U.S. Department of Energy

under Contract DE-AC05-76RL01830

Pacific Northwest National Laboratory

Richland, Washington 99352 


\section{Introduction}

Ferritic stainless steels and other alloys are of great interest to SOFC developers for applications such as interconnects, cell frames, and balance of plant components. While these alloys offer significant advantages (e.g., low material and manufacturing cost, high thermal conductivity, and high temperature oxidation resistance), there are challenges which can hinder their utilization in SOFC systems; these challenges include Cr volatility and reactivity with glass seals. To overcome these challenges, protective coatings and surface treatments for the alloys are under development. In particular, aluminization of alloy surfaces offers the potential for mitigating both evaporation of $\mathrm{Cr}$ from the alloy surface and reaction of alloy constituents with glass seals. Commercial aluminization processes are available to SOFC developers, but they tend to be costly due to their use of exotic raw materials and/or processing conditions. As an alternative, PNNL has developed Reactive Air Aluminization (RAA), which offers a low-cost, simpler alternative to conventional aluminization methods. ${ }^{1,2}$

\section{RAA Fabrication Process}

The Reactive Air Aluminization (RAA) process consists of four primary steps: 1) preparation of aluminum (Al) powder slurry, 2) application onto the alloy surface, 3) heat treatment in air, and 4) cleaning of the aluminized surface. These steps are illustrated schematically in Figure 1 . The slurry is prepared using a mixture of $\mathrm{Al}$ powder and a commercial organic binder system. Application to the alloy surface can be performed via screen-printing, brush painting, dip coating, or spray coating. A typical heating schedule consists of heating in air $\left(3^{\circ} \mathrm{C} / \mathrm{min}\right)$ to $1000^{\circ} \mathrm{C}$, a one hour hold at $1000^{\circ} \mathrm{C}$, and then cooling at $3^{\circ} \mathrm{C} / \mathrm{min}$. During the heat treatment, the surfaces of the $\mathrm{Al}$ particles oxidize, creating an aluminum oxide (alumina) shell around a metallic $\mathrm{Al}$ core. As the temperature exceeds the melting point of $\mathrm{Al}\left(660^{\circ} \mathrm{C}\right)$, the cores of the particles become molten. As a result of the volumetric expansion associated with that phase change, the liquid Al fractures the oxide shells, and flows to the alloy surface. As the heat treatment proceeds, some of the Al diffuses into the alloy while the Al at the surface is oxidized. After the heat treatment is completed, the surface region of the alloy consists of an $\mathrm{Al}$ diffusion layer in the alloy substrate, a thin alumina layer at the surface, and residual alumina shells above the surface. During post-heat treatment cleaning, the residual shells are removed, typically through a brushing process.

\section{Properties of RAA}

Surface composition

Figure 2 shows an aluminized ferritic stainless steel (Crofer22APU) surface. Results of EDS analysis are summarized on the ternary alloy diagram in Figure 3. While oxidized, nonaluminized Crofer22APU develops a Cr-rich oxide scale, the aluminized alloy exhibits a surface composition highly enriched in $\mathrm{Al}$ (the detected Fe content is likely a result of electron beam penetration through the surface layer into the bulk alloy).

\section{Effect of Al particle size}

Variations in the initial Al particle size can lead to significantly different surface composition and morphology of the aluminized alloy. Morphology differences resulting from different aluminum particle sizes are shown in Figure 4. Surface layer characteristics are summarized in Table I. In general, for large particle sizes, the oxidized volume fraction is less than that the amount of molten aluminum, resulting in more extensive diffusion into the alloy substrate, and 
increased surface roughness. On the other hand, if the Al particle size is too small, the oxidized volume ratio is much larger than the amount of molten aluminum, resulting in minimal diffusion into the alloy substrate. Also, due to the thermal expansion difference at the faying interface, the thick alumina layer may de-adhere.

\section{Effect of initial coating thickness}

Differences in the thickness of the applied slurry layer can result in differences in the final surface composition and morphology. For example, Table II shows results for two different coating thicknesses (10 and 160 microns); both were prepared using the same Al powder (3 microns). While both coatings had similar surface roughness and alumina layer thickness, the thicker coating resulted in a much deeper $\mathrm{Al}$ diffusion zone inside the alloy substrate. At present, aluminization is frequently performed using ultrasonically sprayed precursor coatings of $\sim 3-5$ microns thickness. After heat treatment, an Al diffusion depth of 10-15 microns, and a surface roughness of 2-3 microns, is typically observed (see SEM image in Figure 5).

\section{Effect on thermal expansion}

Due to the high coefficient of thermal expansion (CTE) of Al, the diffusion of $\mathrm{Al}$ into the alloy substrate tends to increase its thermal expansion. For example, Figure 6 shows dilatometric results for Crofer22APU ( $0.5 \mathrm{~mm}$ thick) with aluminization treatments based on -325 mesh (44 microns), 3 microns, and 0.1 micron Al powder. Results for non-aluminized Crofer22APU are also shown. The use of -325 mesh $\mathrm{Al}$ powder resulted in a relatively thick coating of variable thickness, resulting in a highly variable CTE, as shown for two nominally identical samples in Figure 6. As expected, decreasing thickness of the Al diffusion layer reduced the difference in CTE compared with the original bare stainless steel (see plots for 3 and 0.1 micron Al particle size in Figure 6).

\section{Oxidation behavior}

Results of oxidation testing of bare and aluminized Crofer22APUat $800^{\circ} \mathrm{C}$ in air are shown in Figure 7. While the bare Crofer22APU showed the expected parabolic mass gain due to Cr-based oxide scale growth, the aluminized steel exhibited no measurable mass gain due to the increased oxidation resistance provided by the alumina surface layer. Representative SEM surface images and cross-section images are shown in Figures 8 and 9 for bare and aluminized Crofer22APU, respectively.

\section{Self-healing behavior}

The presence of a "reservoir" of diffused $\mathrm{Al}$ in the alloy substrate allows for self-healing of surface damage due to scratching, abrasion, etc. Results of a scratch-healing test are shown in Figure 10. For this test, scratches were introduced into the surface of an aluminized Crofer22APU coupon. As shown in the figure, healing of the scratch occurred during a subsequent heat treatment at $800^{\circ} \mathrm{C}$ for 4 hours, although the aluminum content in the healed region was not quite as high as that in the undamaged surface. 


\section{Long-Term Performance of RAA}

To evaluate the long-term performance of the RAA process, AISI441 ferritic stainless steel cell frames and interconnects were aluminized and tested in the SECA CTP stack test fixture for 6,000 hours at $800^{\circ} \mathrm{C}$. After the test, the stack was disassembled, sectioned, and polished for microstructure and interfacial characterization. Four areas of the aluminized AISI 441 were selected for analysis: the fuel side sealing glass/aluminized AISI441 interface, the air side sealing glass/aluminized AISI441 interface, aluminized AISI441 exposed to fuel, and aluminized AISI441 exposed to air. Results of microstructural and chemical analyses are discussed below.

\section{Sealing glass/aluminized AISI441 interface at the fuel side}

Figure 11A shows a typical microstructure of a sealing glass/aluminized AISI441 interface near the seal edge exposed to fuel. The sealing glass was an alkaline earth silicate glass developed at PNNL. A high magnification view of the interface with elemental analysis is shown in Figure 11B. The alumina coating was dense and continuous with relatively uniform thickness of $\sim 1-2$ microns. EDS spot analysis of the dark gray layer (arrow in Figure 11A) confirmed that the major components were $\mathrm{Al}$ and $\mathrm{O}$, with minor amounts of $\mathrm{Fe}, \mathrm{Cr}, \mathrm{Ti}, \mathrm{Nb}$, and $\mathrm{Sr}$ ). No debonding of the thin coating was observed. The dense and continuous nature of the alumina appeared to effectively block the diffusion of $\mathrm{Cr}$ and Fe into the glass matrix. However, there was some interaction between the alumina protective coating and the glass, as evidenced by the substantial amount of $\mathrm{Al}$ in the glass adjacent to the alumina layer (see line scan in Figure 11B). Five spots of Figure 11B were selected for EDS analysis in order to better understand the local chemistry. The results are listed in Table III.

\section{Sealing glass/aluminized AISI441 interface at the air side}

The microstructure of the alumina coating at the air side was different from that on the fuel side, as shown in Figure 12A. Instead of a continuous, dense $\mathrm{Al}_{2} \mathrm{O}_{3}$ layer, there were dark gray precipitates along the glass/metal interface, tentatively identified as $\mathrm{SiO}_{2}$ (spots \#1 and \#5 Table IV). An elemental line scan across the interface (shown in Figure 12B) indicated that Cr (green line), Fe (dark blue line), and Mn (light blue line) diffused from the alloy into the glass. Overall, it appeared that the sealing glass had corroded the alumina protection layer severely, as evidenced by the presence of $\mathrm{Al}$ throughout the 10-15 micron region next to the interface. EDS confirmed the presence of $\mathrm{Ba}, \mathrm{Sr}, \mathrm{Cr}, \mathrm{Ti}$, and $\mathrm{Al}$ in the white precipitates in the sealing glass. Although the glass/metal interface appeared to have remained intact for the duration of the test, it should be noted that $\mathrm{BaCrO}_{4}$ and $\mathrm{SrCrO}_{4}$ can potentially form at the air side due to chemical reaction between oxygen, $\mathrm{Cr}$ in the steel, and the alkaline earth silicate sealing glass. The formation of these chromate phases is undesirable due to their very high CTE, which can degrade the mechanical integrity of the glass/steel interface during thermal cycling, especially if a continuous interfacial layer of chromite is formed.

\section{Aluminized AISI441 exposed to fuel}

In addition to the aluminized region sealed with refractory sealing glass, the fuel side area not covered by sealing glass was also subjected for analysis. A typical alumina coating microstructure at the fuel side is shown in low magnification and high magnification in Figure 13A and Figure 13B, respectively. The alumina coating appeared to be composed of discrete particles of varying color contrast (Figure 13B), as compared to the dense and homogeneous 
color/contrast alumina layer found in regions covered with sealing glass (Figure 11B). Chemical analysis by EDS of selected spots showed that $\mathrm{Al}$ and $\mathrm{O}$ were the major constituents, with minor amounts of $\mathrm{Fe}, \mathrm{Cr}, \mathrm{Ti}$, and $\mathrm{Ba}$ (Table $\mathrm{V}$ ). The presence of $\mathrm{Ba}$ is likely due to vapor phase transport or surface diffusion from the nearby sealing glass. The alumina layer appeared to be well-bonded to the metal substrate, with no de-bonding or spallation observed.

\section{Aluminized AISI441 exposed to air}

For comparison, the aluminized area at the air side without sealing glass was also characterized. The coating and metal interface is shown in low and high magnification in Figure 14A and Figure 14B, respectively. The alumina layer appeared to be continuous, and more homogeneous than the fuel side layer with its discrete particle-like microstructure. The alumina thickness ranged from $\sim 5$ to $\sim 10$ microns, which was similar to the fuel side. Ti and Al oxide particles were also evident (dark grey precipitates; see arrows in Figure 14B). Spot EDS analysis near the metal substrate showed primarily $\mathrm{Al}$ and $\mathrm{O}$ with a minor amount of $\mathrm{Cr}$ ( 0.1 at\%; see Table VI). At the outer surface, small amounts ( $<1$ at \%) of K, Mn, Sr, Ba, Ca, and Fe were detected. The $\mathrm{Sr}, \mathrm{Ba}$, and $\mathrm{Ca}$ were likely from the nearby sealing glass, while $\mathrm{K}$ may have come from the phlogopite mica spacer. The relatively thick alumina layer appeared to be well-bonded after the metallurgical preparation, indicating good adhesion strength.

\section{Summary}

Reactive air aluminization (RAA), developed at PNNL, provides a simple, inexpensive method for creating a protective surface layer of aluminum oxide on alloys such as ferritic stainless steel. The process improves long-term surface stability at elevated temperatures (e.g., $800^{\circ} \mathrm{C}$ ) by reducing the oxidation rate, chemical reactivity, and volatilization of chromium. For more information, please contact Jeff Stevenson (509-372-4697; jeff.stevenson@pnnl.gov).

\section{Acknowledgement}

The work described in this report was funded by the Solid-state Energy Conversion Alliance Core Technology Program (US DOE-Fossil Energy).

\section{References}

1. U.S. Published Pending Application \#2010/029734.

2. J.P. Choi, K.S. Weil, Y. Chou, J.W. Stevenson, and Z.G. Yang, “Development of MnCoO coating with new aluminizing process for planar SOFC stacks,” Int. J. Hydrogen Energy, 36, 4549 (2011). 
Table I. Effect of Al particle size on surface properties; unit: micron.

\begin{tabular}{|c|c|c|c|}
\hline Al particle size & $\begin{array}{c}-325 \\
\text { mesh }\end{array}$ & $\begin{array}{c}3 \\
\text { microns }\end{array}$ & 0.1 micron \\
\hline Coating thickness & 160 (hand stencil printing) \\
\hline Average surface roughness & 50 & 6 & 0 \\
\hline Alumina thickness & 0.5 & 0.5 & 160 \\
\hline Al diffusion depth & 120 & 105 & 0 \\
\hline
\end{tabular}

Table II. Effect of coating thickness on surface properties; unit: micron.

\begin{tabular}{|c|c|c|}
\hline Al particle size & 3 & 3 \\
\hline Coating thickness & 160 & 10 \\
\hline Average surface roughness & 6 & 4 \\
\hline Alumina thickness & 0.5 & 0.5 \\
\hline Al diffusion depth & 105 & 65 \\
\hline
\end{tabular}

Table III. EDS spot analysis of selected spots in Figure 11B (atomic \%).

\begin{tabular}{|c|r|r|r|r|r|}
\hline Element/spot & \multicolumn{1}{|l|}{1} & \multicolumn{1}{|c|}{2} & \multicolumn{1}{|c|}{3} & \multicolumn{1}{c|}{4} & \multicolumn{1}{c|}{5} \\
\hline $\mathrm{O} \mathrm{K}$ & 63.01 & 62.13 & 69.82 & 65.41 & 63.62 \\
\hline $\mathrm{Al} \mathrm{K}$ & 35.07 & 13.20 & 2.63 & & \\
\hline $\mathrm{Si} \mathrm{K}$ & & 8.59 & 3.76 & 9.90 & 18.97 \\
\hline $\mathrm{Ti} \mathrm{K}$ & 0.35 & & & & \\
\hline $\mathrm{Cr} \mathrm{K}$ & 0.32 & 0.16 & & & \\
\hline $\mathrm{Fe} \mathrm{K}$ & 0.60 & 1.66 & 0.63 & 0.21 & \\
\hline $\mathrm{Sr} \mathrm{L}$ & 0.15 & 13.48 & 12.85 & 11.63 & 15.83 \\
\hline $\mathrm{Y} \mathrm{L}$ & & & 8.39 & 11.44 & \\
\hline $\mathrm{Ba} \mathrm{L}$ & & 0.77 & 1.91 & 1.41 & 1.48 \\
\hline $\mathrm{Nb} \mathrm{L}$ & 0.51 & & & & \\
\hline
\end{tabular}


Table IV. EDS spot analysis of selected spots in Figure 12B (atomic \%).

\begin{tabular}{|c|r|r|r|r|r|}
\hline Element/spot & \multicolumn{1}{|c|}{1} & \multicolumn{1}{|c|}{2} & \multicolumn{1}{|c|}{3} & \multicolumn{1}{|c|}{4} & \multicolumn{1}{|c|}{5} \\
\hline $\mathrm{O} \mathrm{K}$ & 63.78 & 65.11 & 68.89 & 63.82 & 59.92 \\
\hline $\mathrm{Na} \mathrm{K}$ & & & 0.66 & 0.43 & \\
\hline $\mathrm{Al} \mathrm{K}$ & 3.29 & 3.20 & 2.24 & 13.29 & 0.40 \\
\hline $\mathrm{Ti} \mathrm{K}$ & 26.30 & 1.48 & & 15.14 & 22.56 \\
\hline $\mathrm{Cr} \mathrm{K}$ & 0.12 & 0.47 & 4.39 & & 0.16 \\
\hline $\mathrm{Mn} \mathrm{K}$ & 2.25 & 28.96 & 7.98 & 0.36 & 11.76 \\
\hline $\mathrm{Fe} \mathrm{K}$ & & & 0.97 & & \\
\hline $\mathrm{Sr} \mathrm{L}$ & 4.26 & 0.42 & 0.37 & 0.28 & 5.19 \\
\hline $\mathrm{Ba} \mathrm{L}$ & & & 7.51 & 1.50 & \\
\hline $\mathrm{Nb} \mathrm{L}$ & & & 6.18 & 1.50 & \\
\hline
\end{tabular}

Table V. EDS spot analysis of selected spots in Figure 13B (atomic \%).

\begin{tabular}{|c|r|r|r|}
\hline & & \multicolumn{1}{l|}{2} & \multicolumn{1}{l|}{3} \\
\hline O K & 66.03 & 64.09 & 64.58 \\
\hline Al K & 28.43 & 30.86 & 31.05 \\
\hline Si K & 0.27 & & 1.84 \\
\hline Ti K & & 0.09 & \\
\hline Cr K & 2.96 & 1.52 & 0.78 \\
\hline Fe K & 2.31 & 3.44 & 1.26 \\
\hline Ba L & & & 0.49 \\
\hline
\end{tabular}

Table VI. EDS spot analysis of selected spots in Figure 14B (atomic \%).

\begin{tabular}{|c|r|r|}
\hline Element/spot & \multicolumn{1}{|c|}{1} & \multicolumn{1}{c|}{2} \\
\hline O K & 61.99 & 64.66 \\
\hline Al K & 37.57 & 32.48 \\
\hline K K & & 0.81 \\
\hline Ti K & 0.07 & \\
\hline Cr K & 0.10 & \\
\hline Fe K & 0.27 & 0.19 \\
\hline Ca K & & 0.34 \\
\hline Mn K & & 0.96 \\
\hline Sr L & & 0.15 \\
\hline Ba L & & 0.40 \\
\hline
\end{tabular}




\section{A New Concept: Reactive Air Aluminizing}

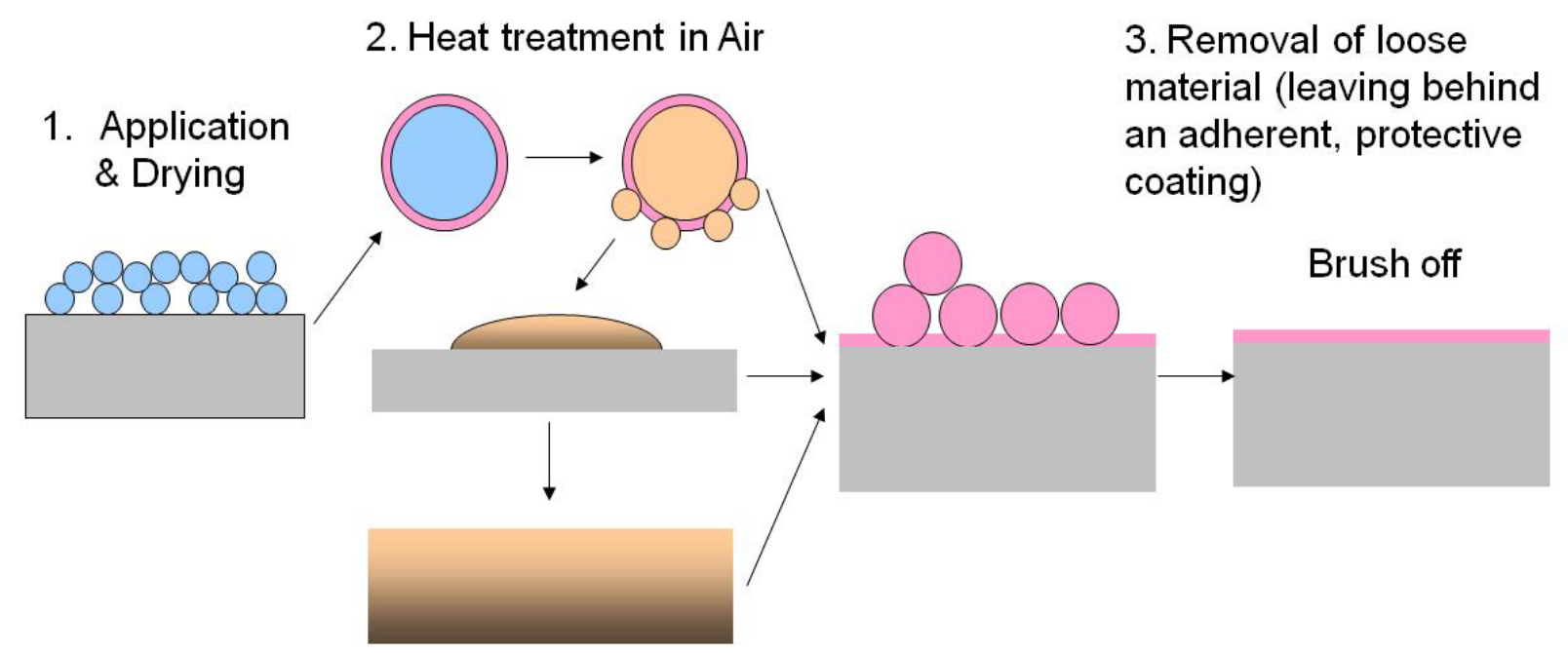

Figure 1. Schematic illustration of the Reactive Air Aluminizing process.

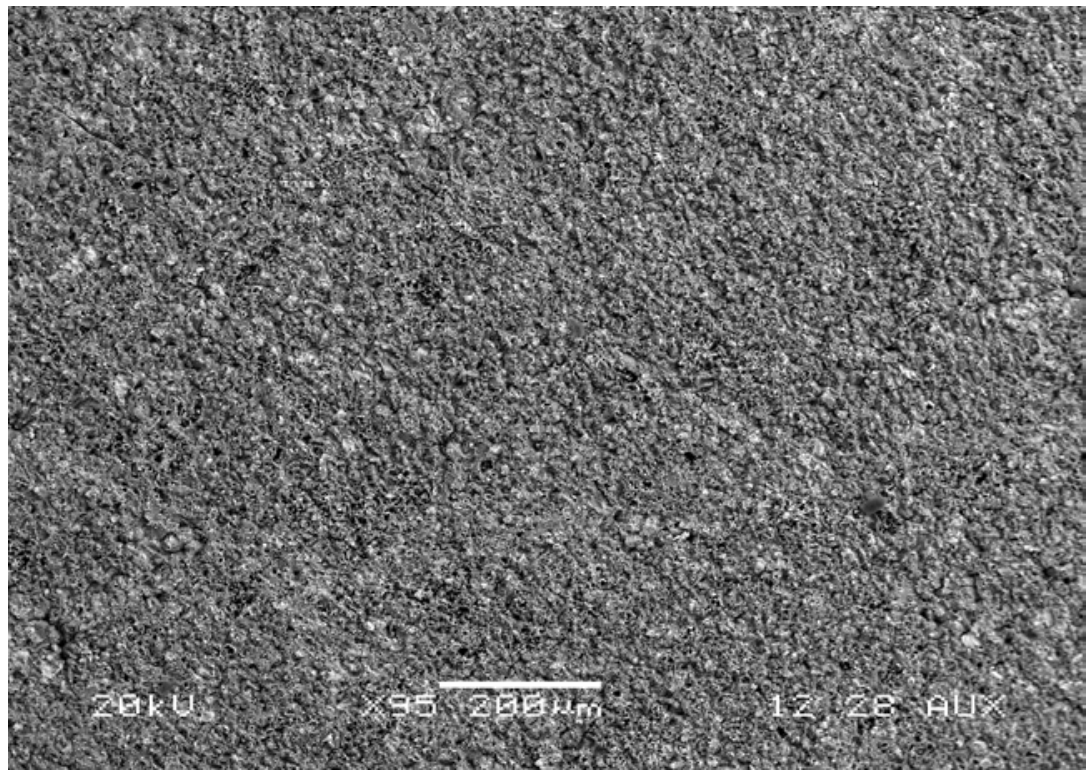

Figure 2. Surface SEM micrograph of aluminized Crofer22APU. 


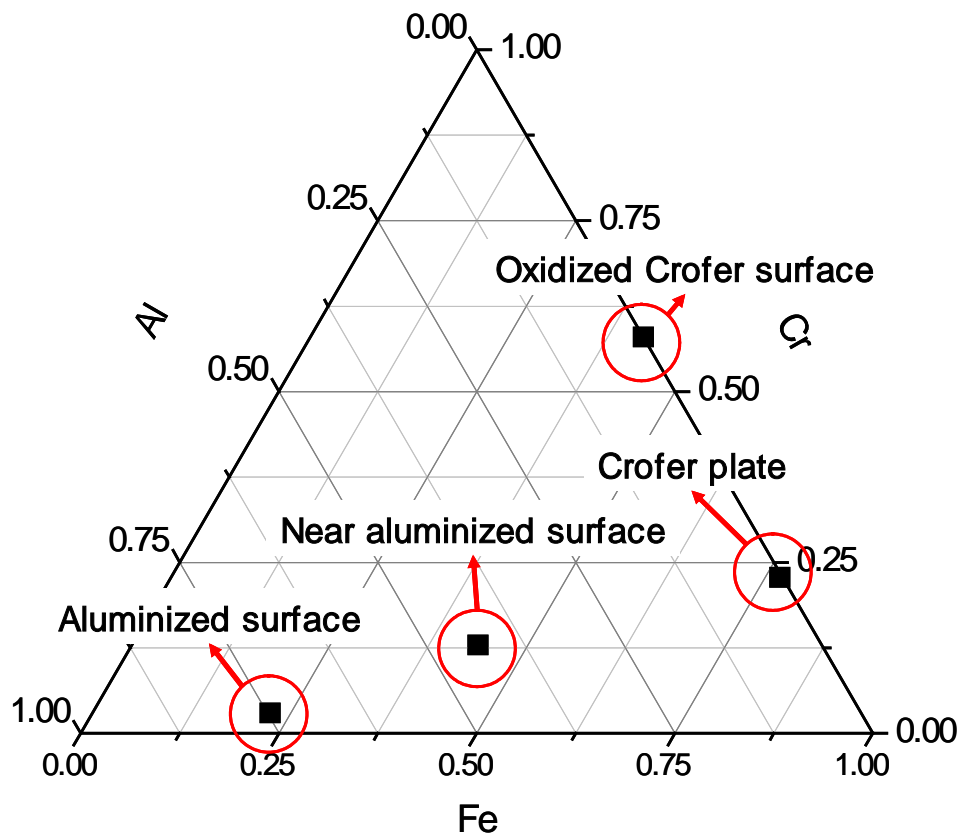

Figure 3. Results of EDS analysis on aluminized and non-aluminized Crofer22APU. 


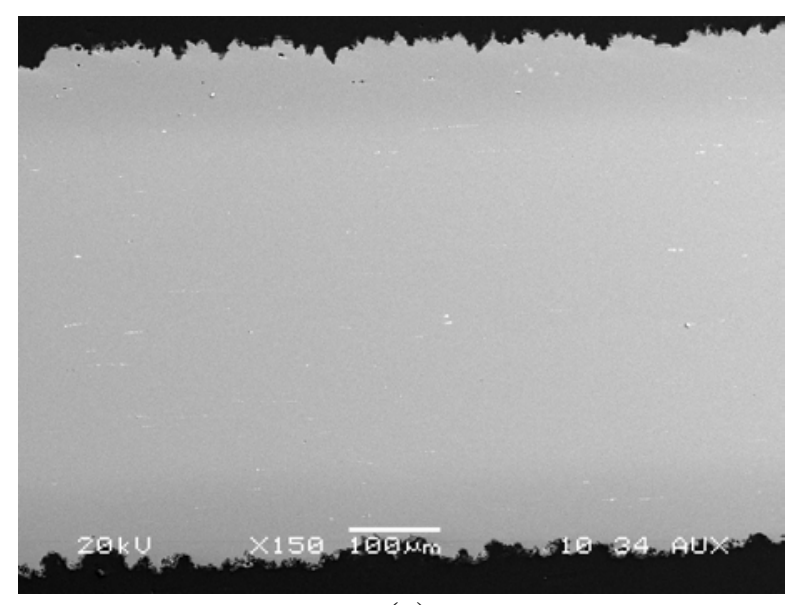

(a)

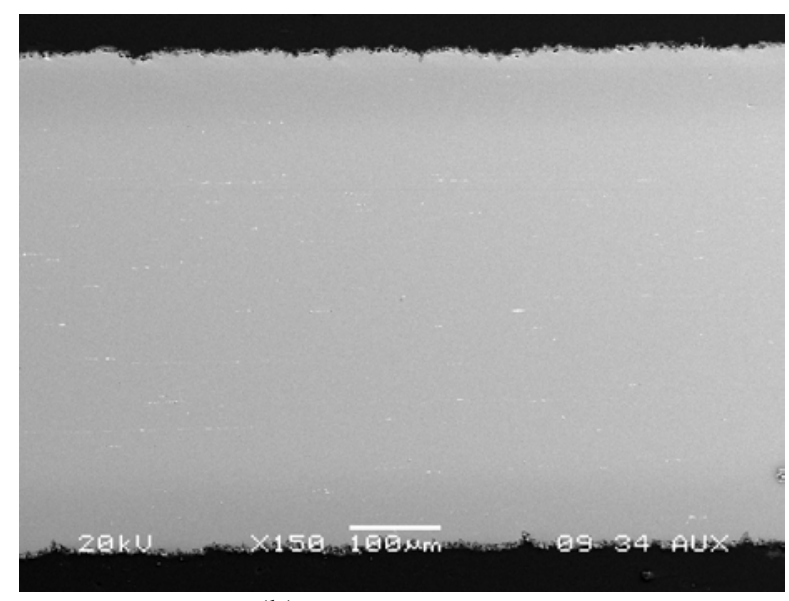

(b)

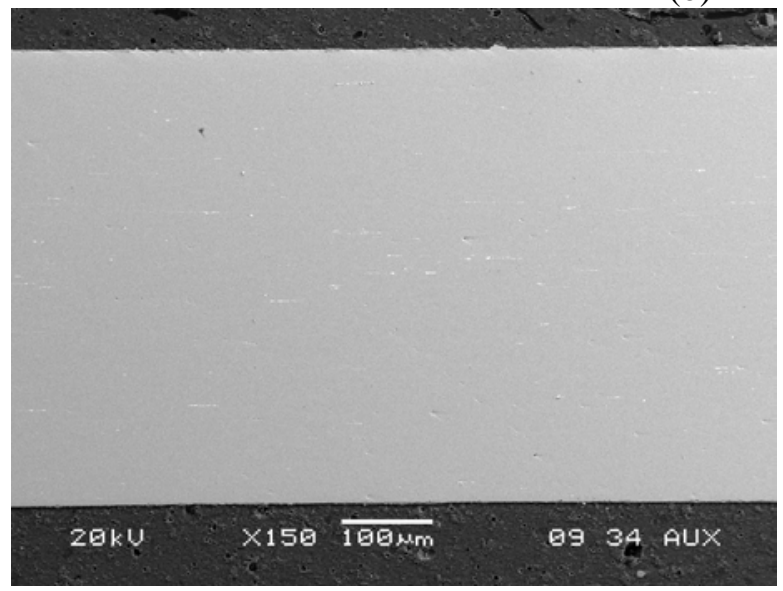

(c)

Figure 4. Cross section SEM images of aluminized Crofer22APU. Three different Al particle sizes were used in the aluminization process: (a) -325 mesh, (b) $3 \mu \mathrm{m}$, (c) $0.1 \mu \mathrm{m}$ 


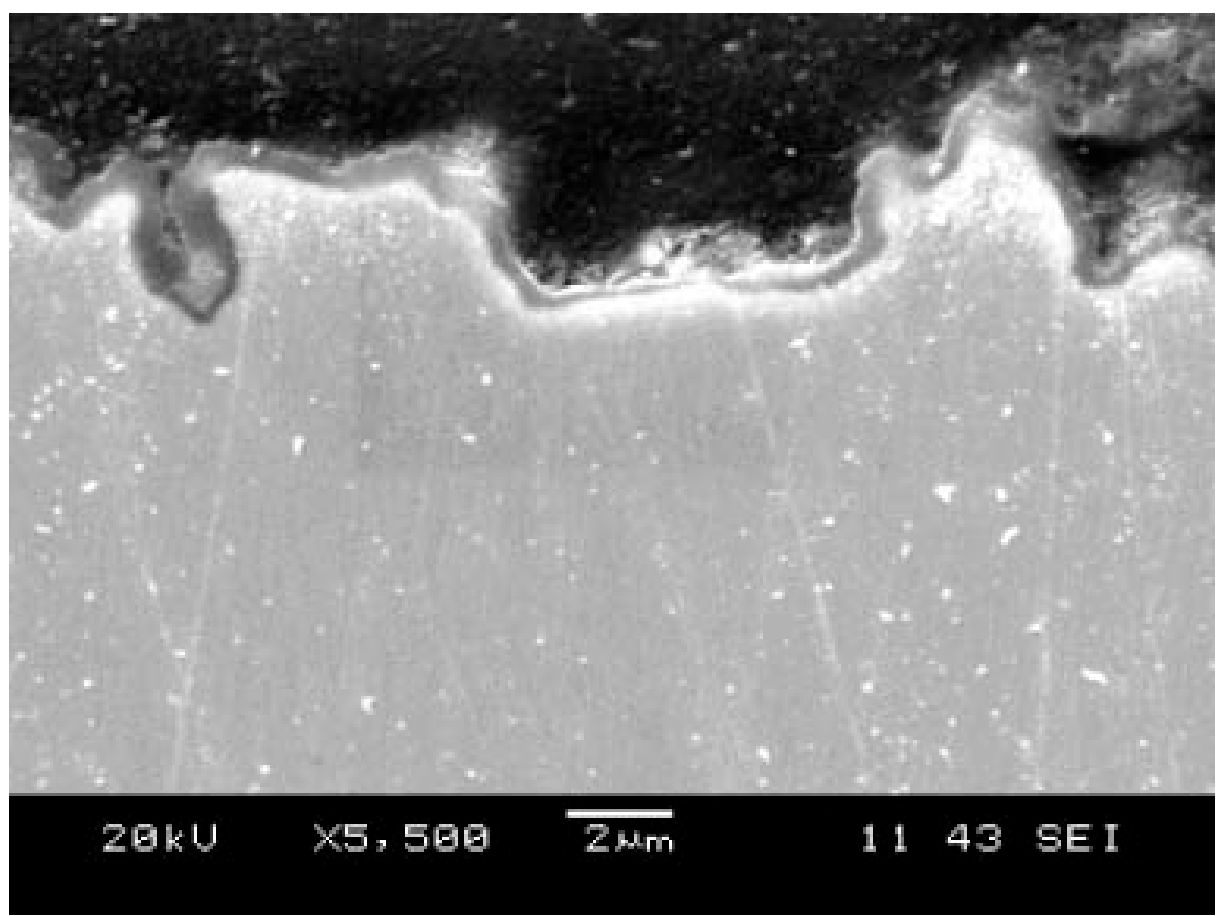

Figure 5. Cross-sectional SEM image of aluminized surface fabricated from ultrasonically sprayed Al coating.

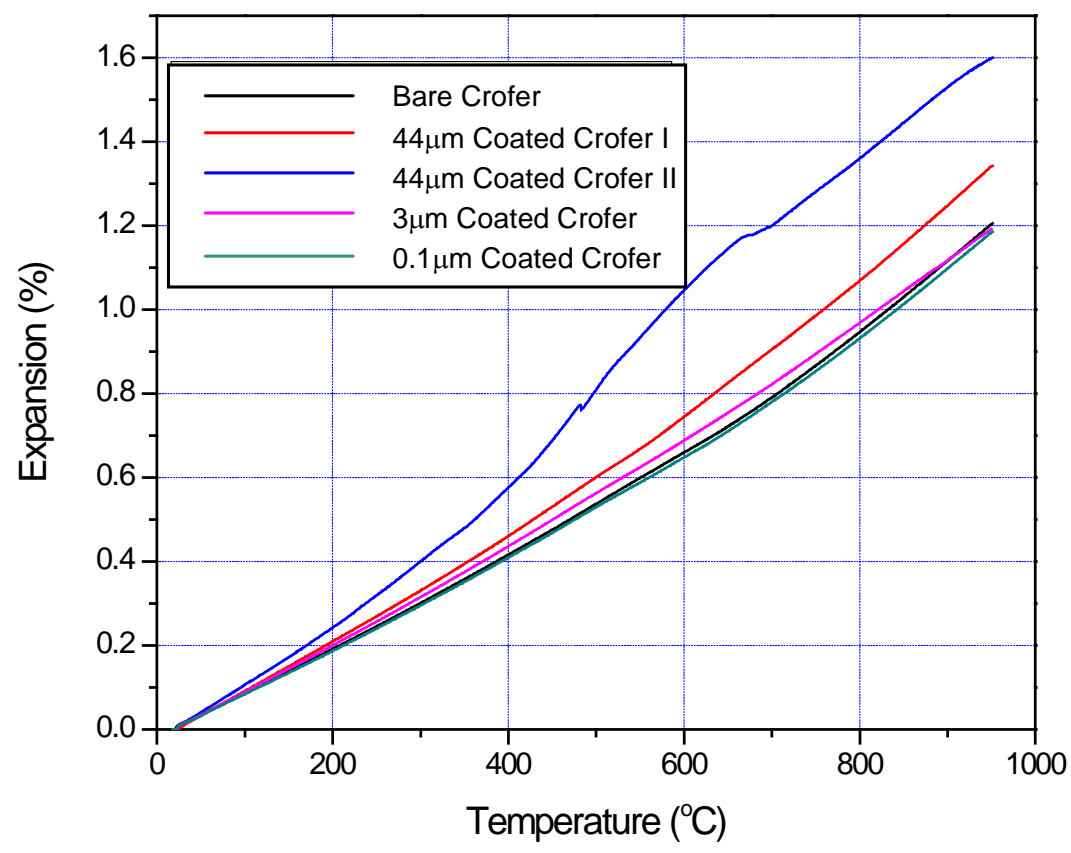

Figure 6. Thermal expansion measurements with various coating starting material sizes. 


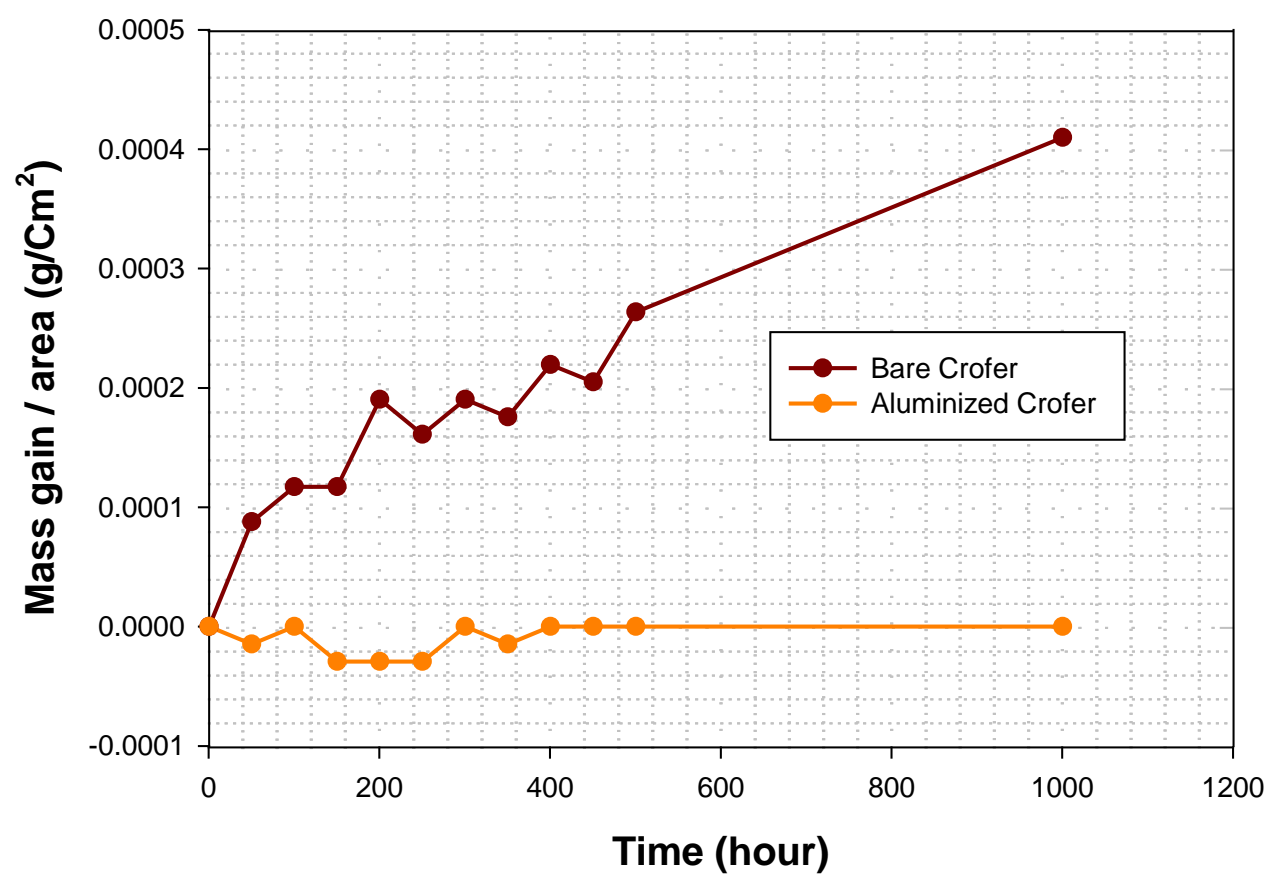

Figure 7. Oxidation kinetics test results for bare and aluminized Crofer22APU. 

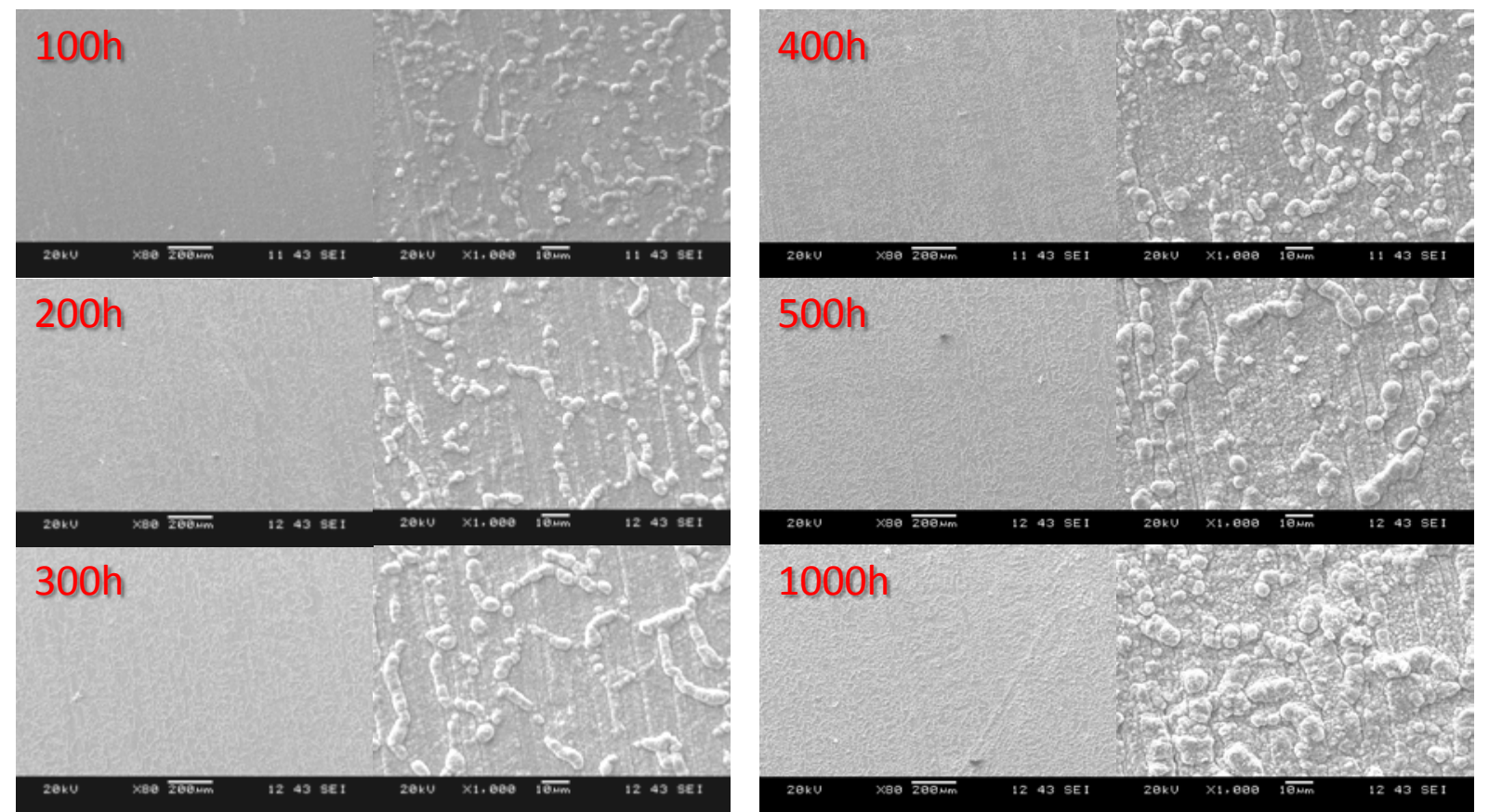

(a)

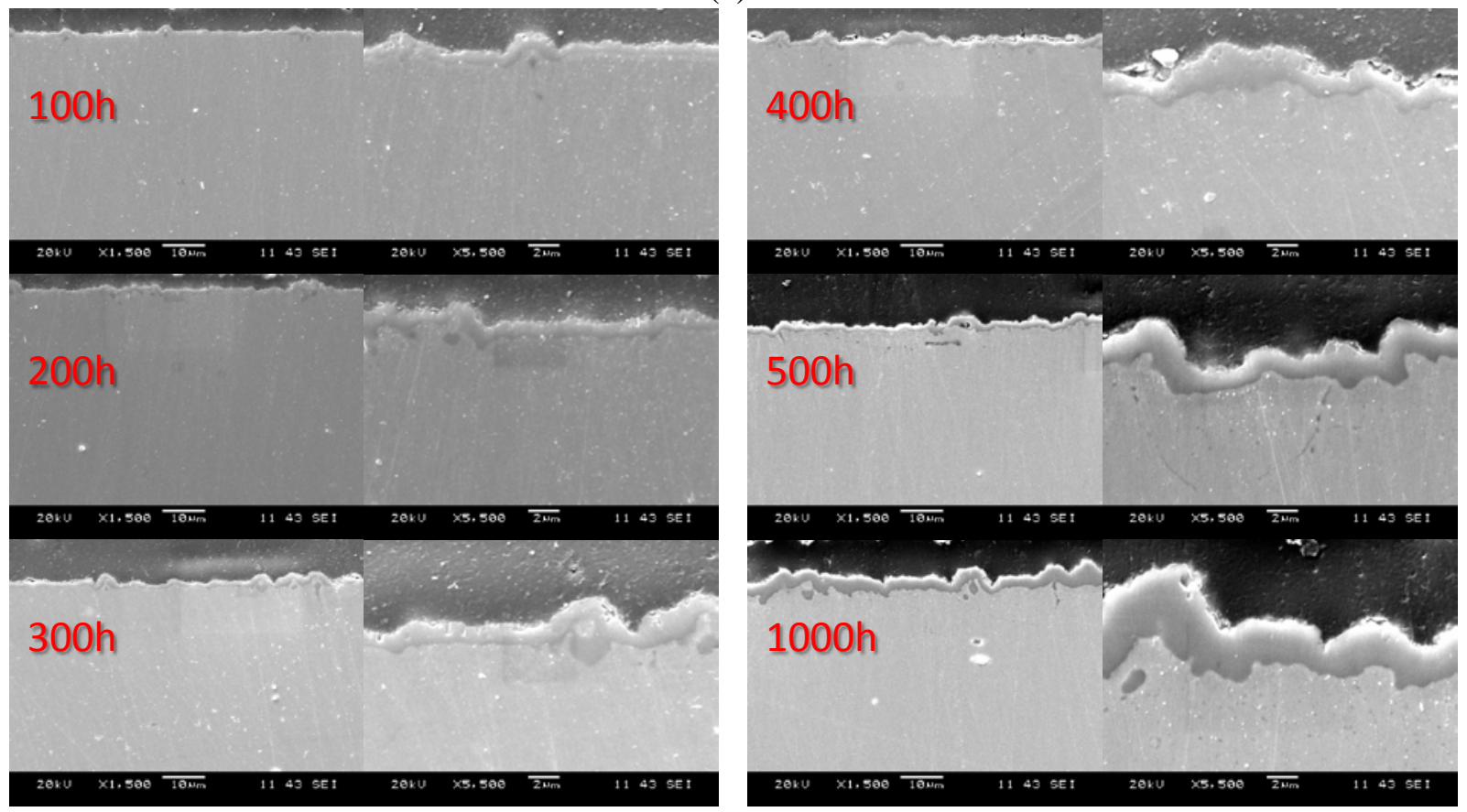

(b)

Figure 8. Bare Crofer22APU oxidized at $800^{\circ} \mathrm{C}$ for the indicated times: a) SEM surface images and b) SEM cross-section images. 

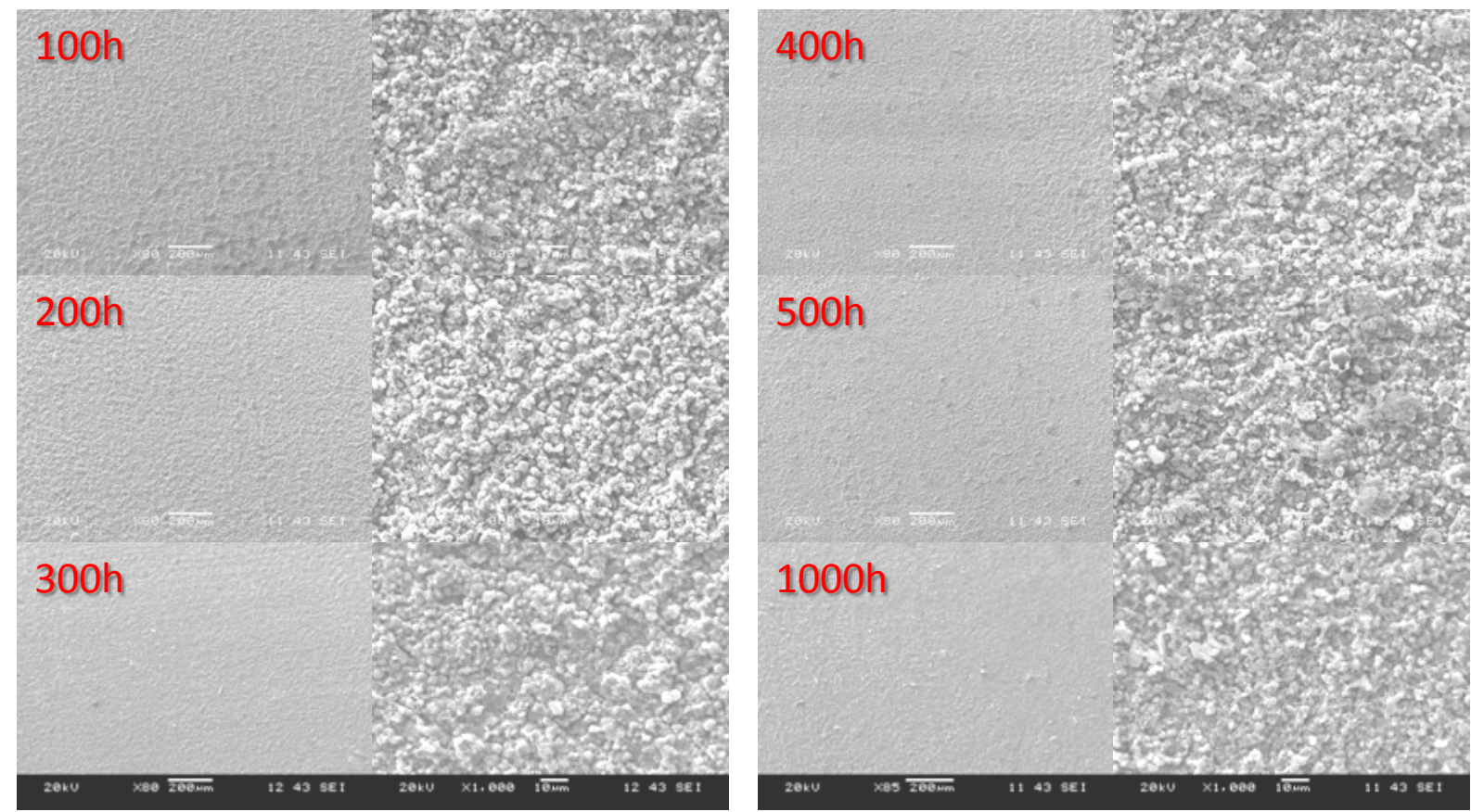

(a)
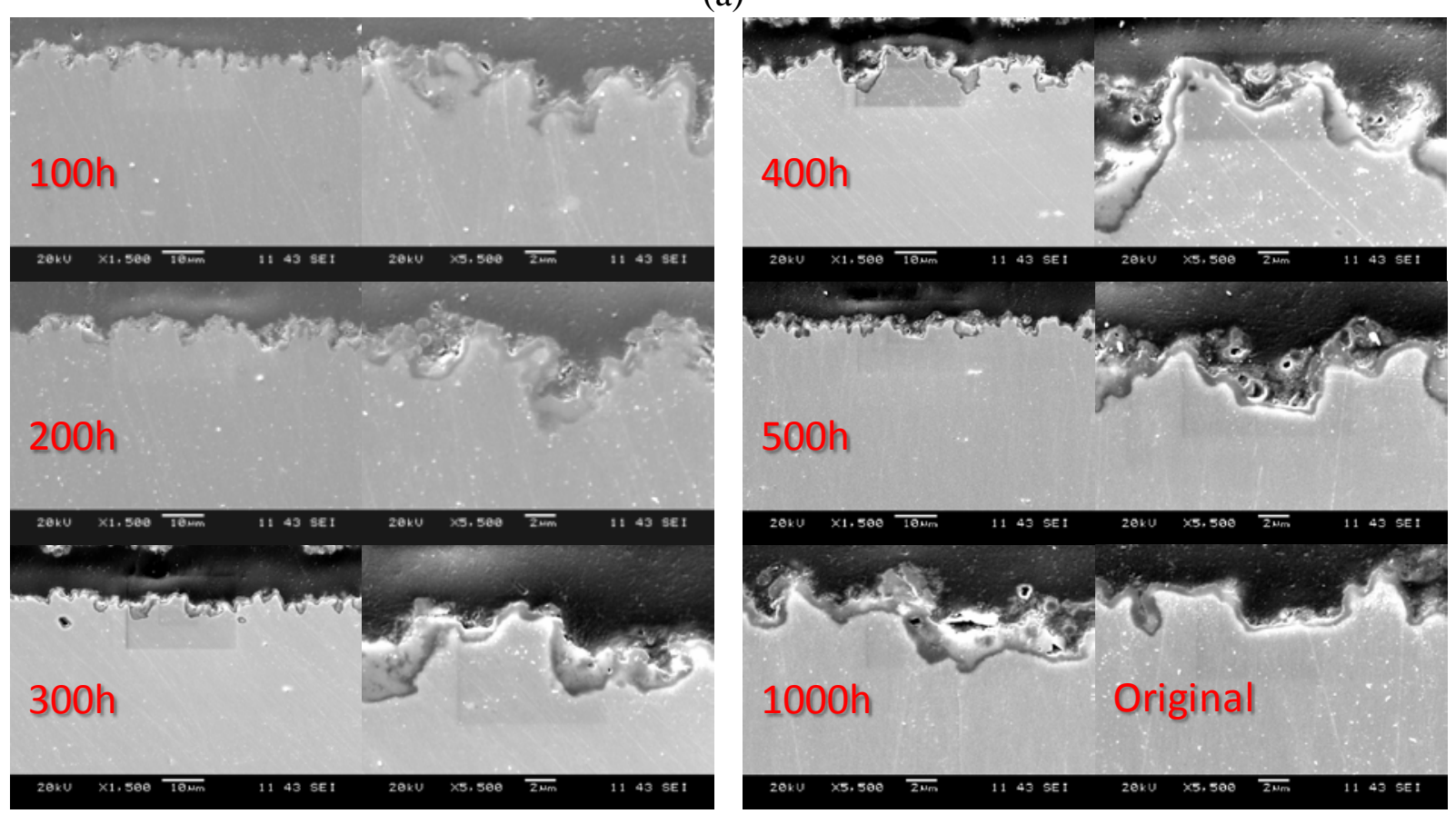

(b)

Figure 9. Aluminized Crofer22APU oxidized at $800^{\circ} \mathrm{C}$ for the indicated times: a) SEM surface images and b) SEM cross-section images. 


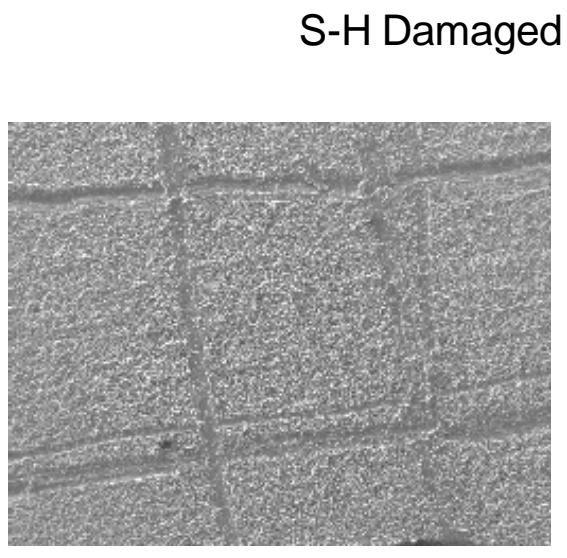

S-H whole surface

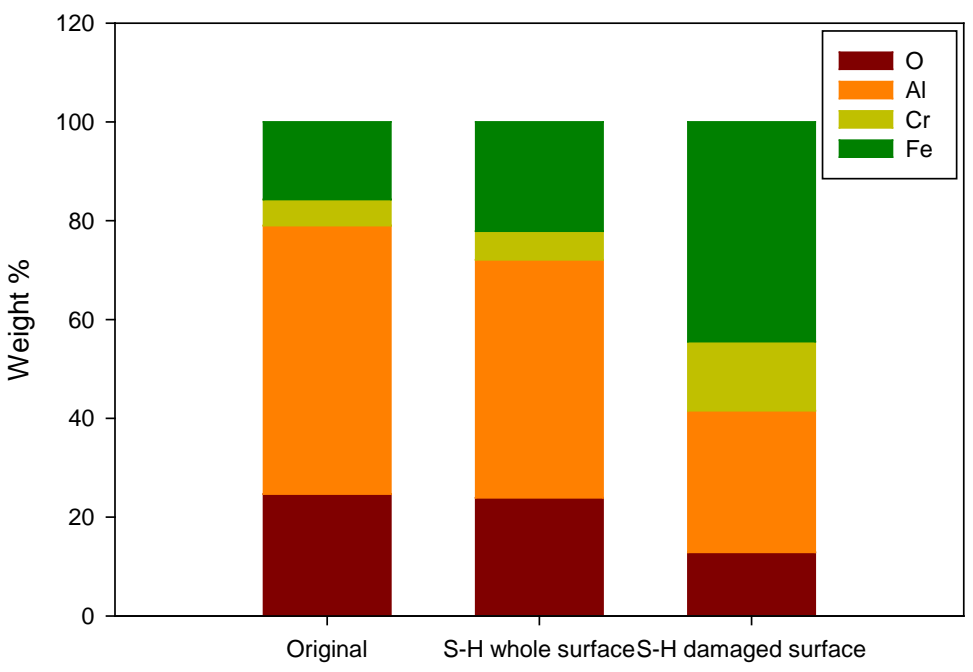

Figure 10 . Results of self healing test $\left(800^{\circ} \mathrm{C}, 4\right.$ hours). 


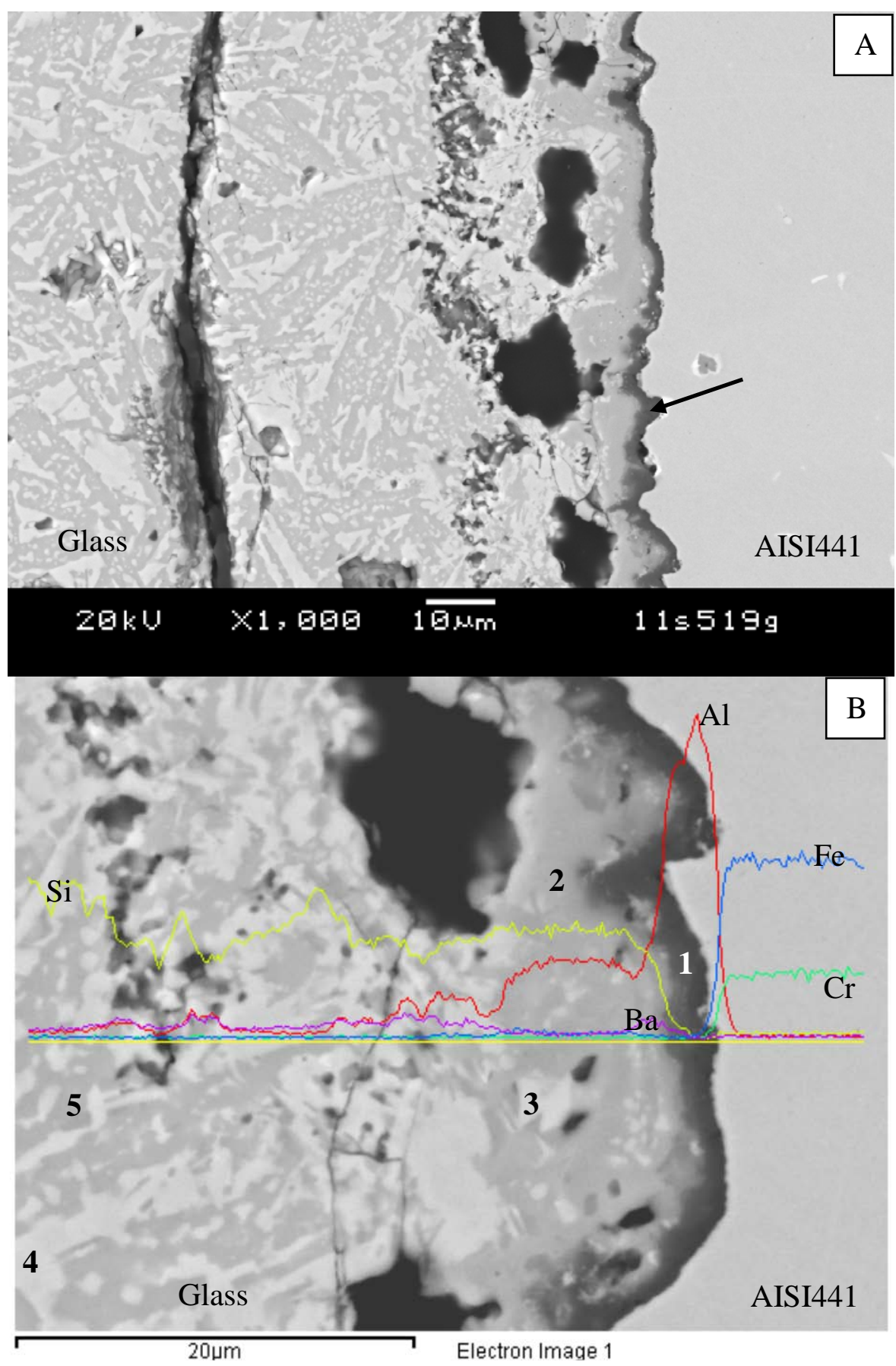

Figure 11. (A) Typical microstructure at the sealing glass/aluminized AISI441 interface at fuel side; (B) a high magnification of the circled area with elemental line scans. Chemical analyses of five selected spots (1-5) are listed in Table III. 


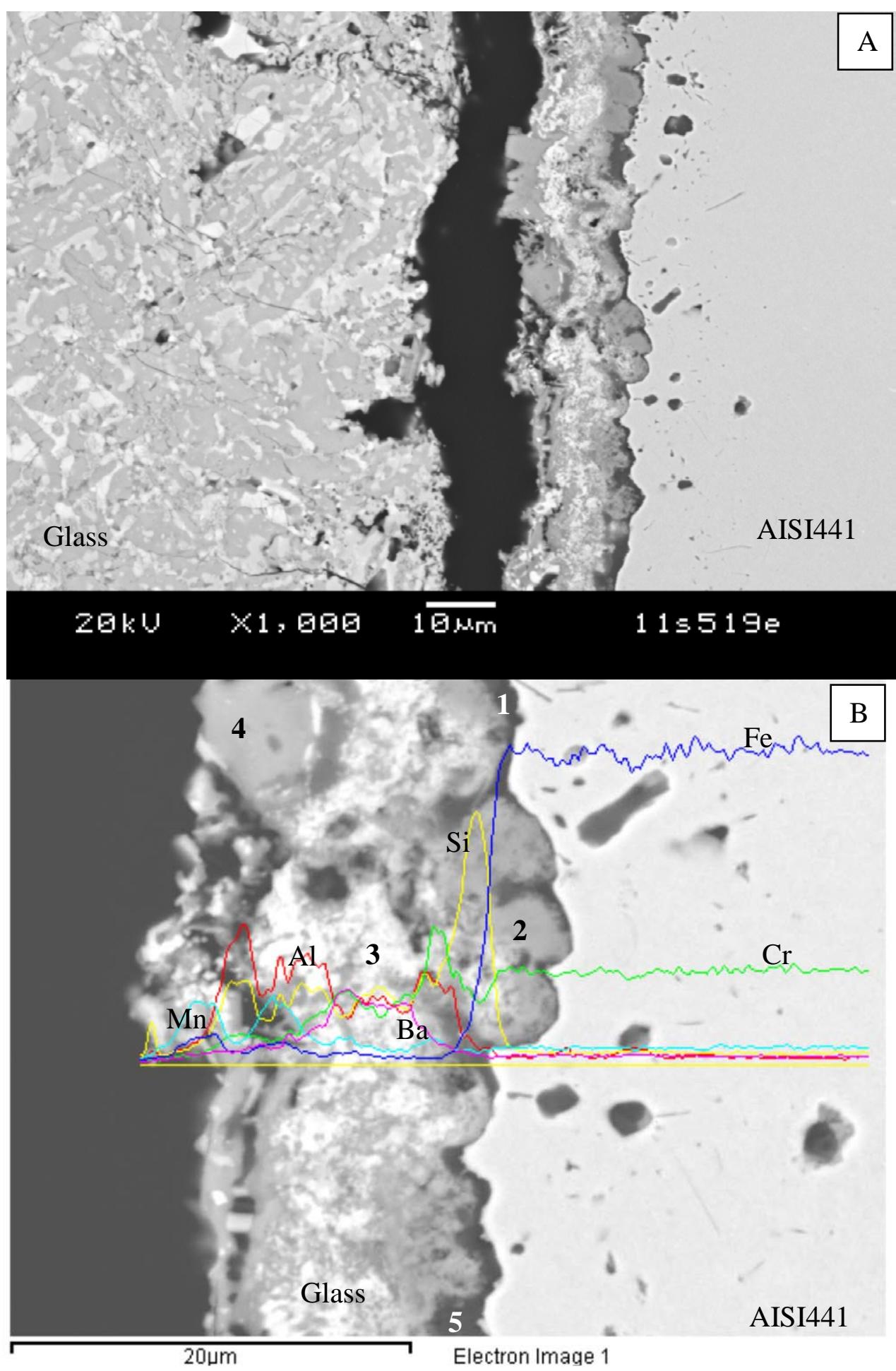

Figure 12. (A) Typical microstructure at the sealing glass/aluminized AISI441 interface at air side; (B) a high magnification of the circled area with elemental line scans. Chemical analyses of four selected spots (1-4) are listed in Table IV. 


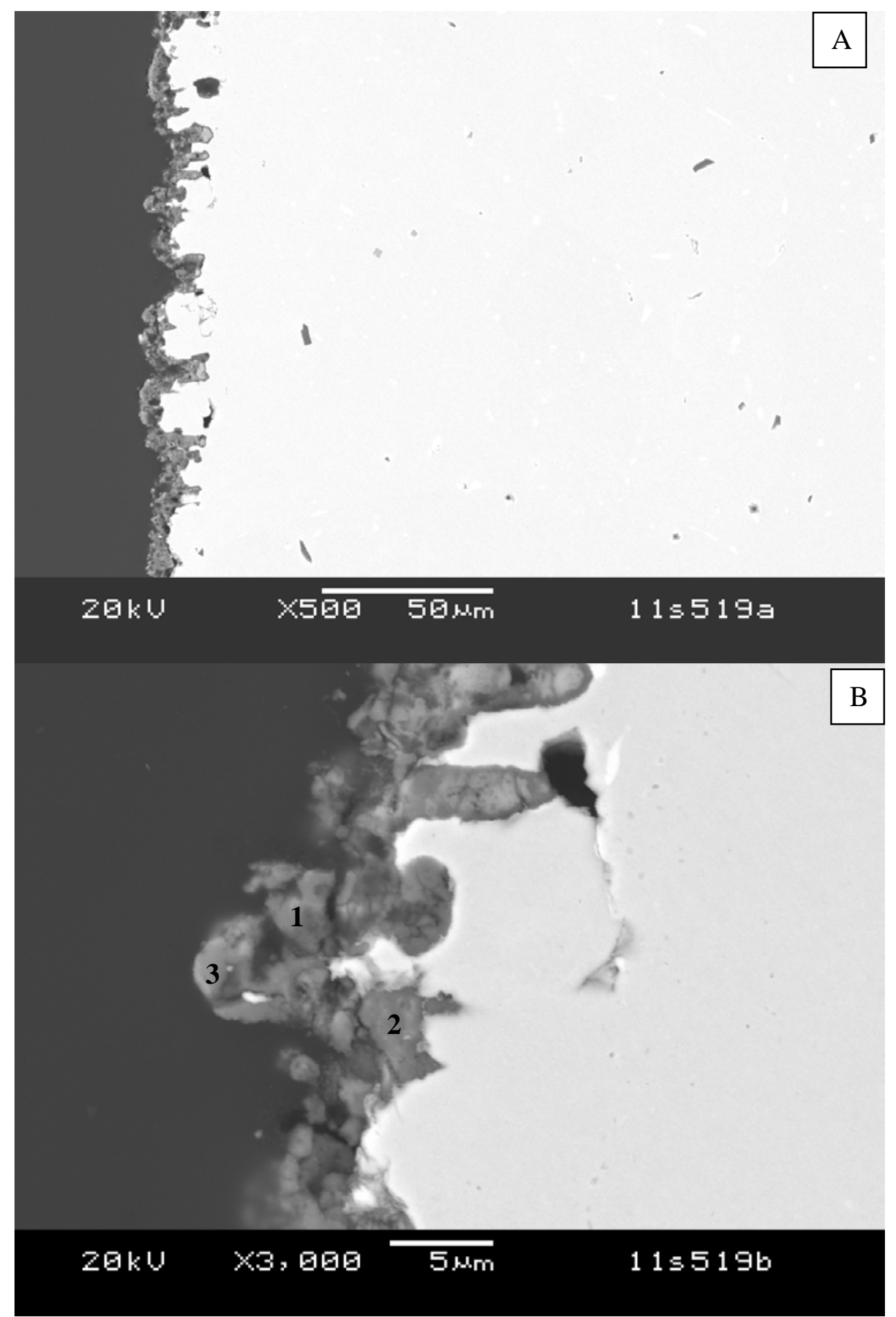

Figure 13. (A) Typical microstructure of the fuel side aluminized AISI441; (B) a high magnification of the outer surface. Chemical analyses of three selected spots $(1,2$, and 3$)$ are listed in Table V. 


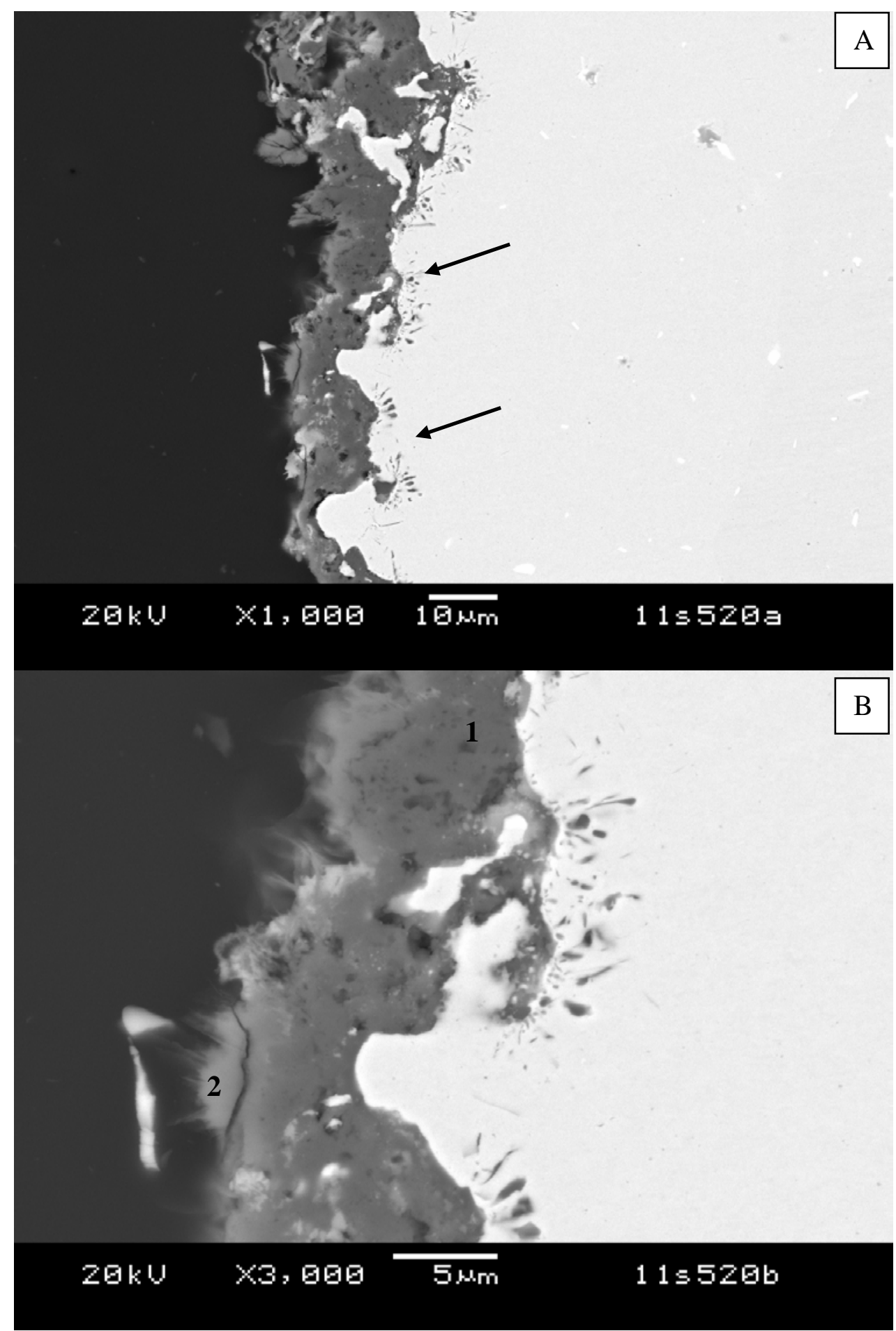

Figure 14. (A) Typical microstructure of the air side aluminized AISI441; (B) a high magnification of the circled area with elemental line scans. Chemical analyses of two selected spots (1 and 2) are listed in Table VI. Arrows in 14A shows the typical Al or Ti containing precipitates from internal oxidation. 